\title{
Wetbud - A Free Water Budget Modeling Tool for Created Wetland Design
}

\author{
Stephen Stone ${ }^{1,2}$, Zach Agioutantis ${ }^{3 *}$, G. Richard Whittecar ${ }^{2}$, W. Lee Daniels ${ }^{1}$, Tess Thompson ${ }^{1}$ and Kerby Dobbs ${ }^{2}$ \\ ${ }^{1}$ Virginia Tech, Blacksburg, VA, USA \\ 2 Old Dominion University, Norfolk, VA, USA \\ ${ }^{3}$ University of Kentucky, Lexington, KY, USA
}

\begin{abstract}
A common result of Environmental Impact Assessments associated with mining projects is the construction of new wetlands in areas disturbed by mining operations. Where appropriate, this mitigation may be considered an integral part of the mine reclamation process under the principles of sustainable development in the minerals industry. Wetbud is a new tool for estimating wetland water budgets using available weather data and site-specific topographic, soil and geohydrologic data, coupled with mass balance mathematics. Wetbud is primarily intended as a planning tool for use in the design of created wetlands, but it can also be applied to native wetlands or wetland restoration sites where the required input parameters can be specified. Wetbud can be run in its basic form where wetland topography, soil parameters and groundwater flux are simplified, or in the advanced form, where these parameters are included in a more complex approach via integration of the MODFLOW package, a free 3D program that was developed by the United States Geological Survey. Both versions can also include overbank flow hydrology sources and the advanced form can also model sloping and irregular topography. The program downloads weather data from the nearest applicable station and selects appropriate wet-normal-dry (W-N-D) years following a modest user data clean-up step. Wetbud also has the ability to utilize existing short-term (e.g. 6 to 9 months) groundwater data from an up-gradient well to simulate longer-term groundwater level inputs for the selected W-N-D years. In addition, Wetbud features a "Wizard" version that comes pre-loaded with 14 pre-selected weather data sets for all areas of Virginia that can develop a simple monthly water budget in less than 15 minutes - a feature that could be expanded anywhere geographically with historic weather data.
\end{abstract}

Keywords: wetlands, design tool, reclamation

\section{Introduction / Background}

Unfortunately, some mining projects require the disturbance of wetland areas in order to carry out mining operations. As a result of this disturbance, wetland mitigation may become an integral part of the mine reclamation process. Wetbud is a tool for estimating wetland water budgets using available weather data and site-specific topographic, soil, and geohydrologic data. Wetbud is primarily intended as a planning tool for use in the design of created wetlands, but it can also be applied to native wetlands where the required input parameters can be specified. The tools made available within Wetbud make it easier for developers to design successful wetlands. Wetbud can be run in the Basic form where wetland topography, soil parameters, and groundwater flux are simplified or in the Advanced form where these parameters are included in a more complex approach.

Basic Scenarios use simple mass balance and level pool routing routines to quantify the inputs and outputs of a wetland water budget on a monthly basis. In the Basic Model, the wetland is conceptualized as a "leaky swimming pool," with a flat, level bottom and vertical side walls. When water is added to the wetland, it is assumed the wetland water surface instantaneously adjusts to a flat water surface. Water is not routed through the wetland; all surface water above the weir elevation is considered outflow and is removed from the wetland each month. Users must define the overall dimensions of the "swimming pool," including an average wetland surface elevation (the bottom of the swimming pool), a wetland surface area, and a depth to weir (depth of water in the wetland, above which outflow occurs). For wetlands with highly irregular topography, it is recommended that the user determine the wetland water volume below the outlet weir elevation using detailed topographic data (or maps) and then divide the actual wetland volume by the actual wetland surface area to determine an average depth to use in the Basic Model. The elevation of the wetland surface would then be set as the outlet elevation minus the average wetland depth and the depth to weir would be set as the average depth.

The Advanced Model of Wetbud is a Graphical User Interface (GUI) for the USGS modular finite difference groundwater model, MODFLOW (Harbaugh et al 2000, Harbaugh 2005). MODFLOW-NWT is a Newton formulation for MODFLOW-2005 and is used for solving problems that involve the drying and rewetting of cells (Niswonger et al 2011). The Newton solver used in the MODFLOW-NWT model can compensate for the numerical instabilities caused by the large water level fluctuations typical of many wetland hydroperiods. The ability of

* Corresponding Author: Z.Agioutantis, zach.agioutantis@uky.edu, phone: +1 859-2572953

Copyright @ 2017 Canamaple Academia Services, http://press.camdemia.ca

DOI: 10.15273 /gree.2017.02.033 


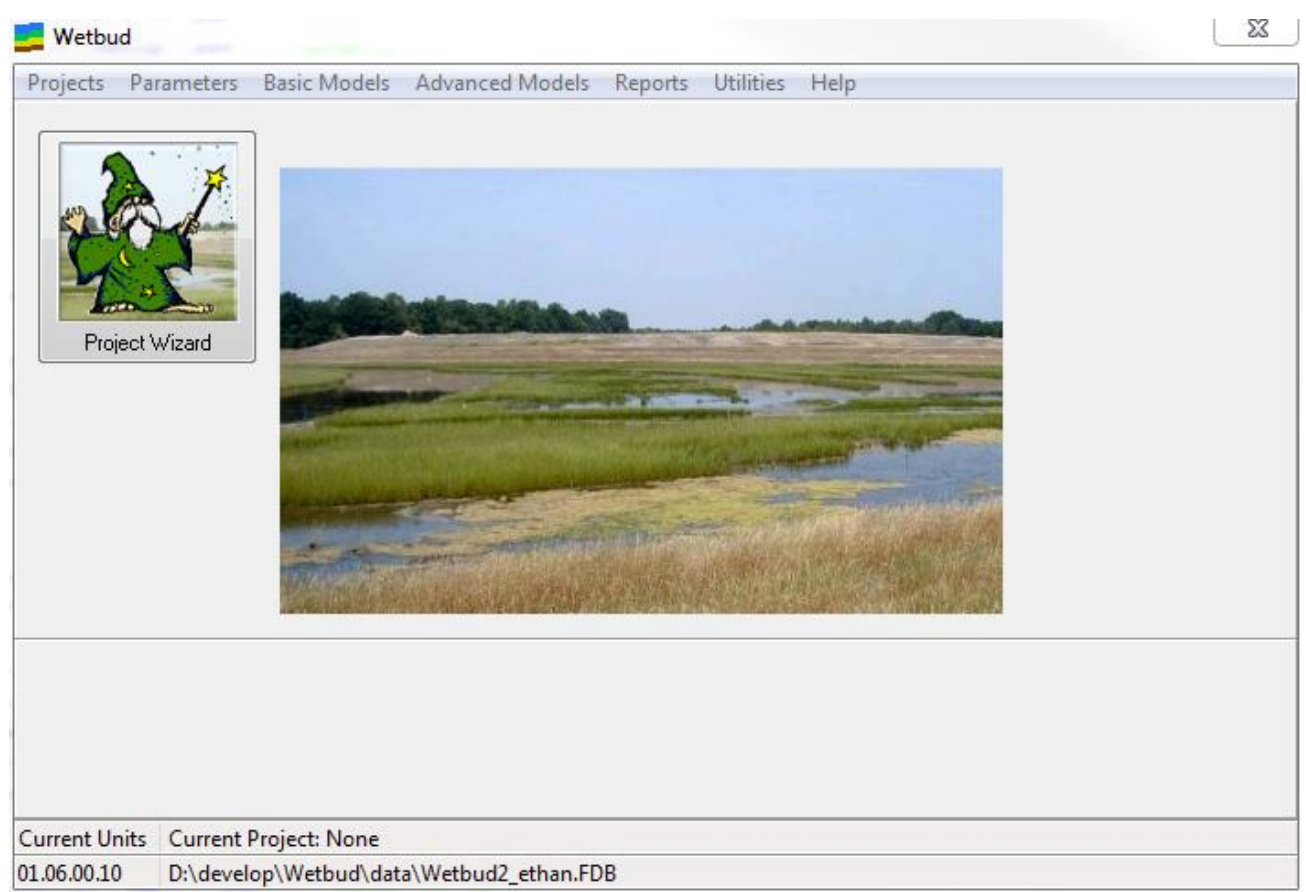

Figure 1. Wetbud main application window.

MODFLOW-NWT to achieve model convergence with the drying and rewetting of cells in the model makes it a more robust software package for wetland water budget modeling than other MODFLOW versions.

Using MODFLOW, the wetland is described mathematically as one or multiple horizontal layers. Each layer is subdivided using a uniform grid, resulting in a "wetland box" formed by similarly sized building blocks. Water storage and flow properties can vary for each block. Using Darcy's Law and a basic water balance, water storage within each block and water flow between the blocks are calculated and summarized on a specified basis.

While Wetbud has a number of different options, the capabilities of MODFLOW-NWT have been optimized so that even users unfamiliar with the MODFLOW software can construct, edit, and run models. Model setup and analysis for the Advanced module requires more detailed information about the proposed wetland site than for the Basic module. However, the required meteorological information for the Advanced module is the same as for the Basic module and Wetbud allows the user to access and utilize stored Basic module meteorological data within the Advanced module. Advanced module results are provided as head values within every cell of the user-specified finite difference grid for each user-specified time step.

\section{System Architecture}

Figure 1 shows the main application window with the main menu options for Projects, Parameters, Basic Models, Advanced Models, Reports Utilities, and Help, as well as a button for the Project Wizard. At the bottom of the main form, basic information is provided, such as the version of the executable file, the directory path of the used database and the name of the currently selected project, as well as the units for the project.

Due to the large data sets used in wetland design, Wetbud was designed as a database-driven application. The data management system consists of more than 100 interconnected data tables and more than 90 stored procedures. It was developed as a client/server database system using Firebird 2.5 (an open source relational database system) as the back end database system. In a standalone environment the database server is installed on the same Windows computer as the front end application. Access to the database is then immediate as shown in Figure 2. Wetbud can also be easily used on a network system where multiple users can access the same database through a Local Area Network (LAN) (Figure 3).

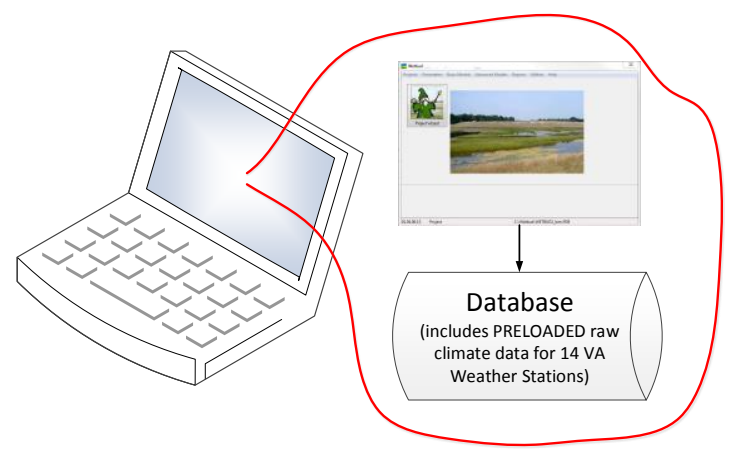

Figure 2. Standalone installation.

The system front end, which is used to setup the necessary parameters, enter and edit the data, perform necessary calculations, connect to the web for data retrieval and mapping information, and other functions, is currently implemented through a Windows-based application. This application, which has been tested on Windows 7, 8.1 and 10 as well as some Windows Server editions, includes more than 


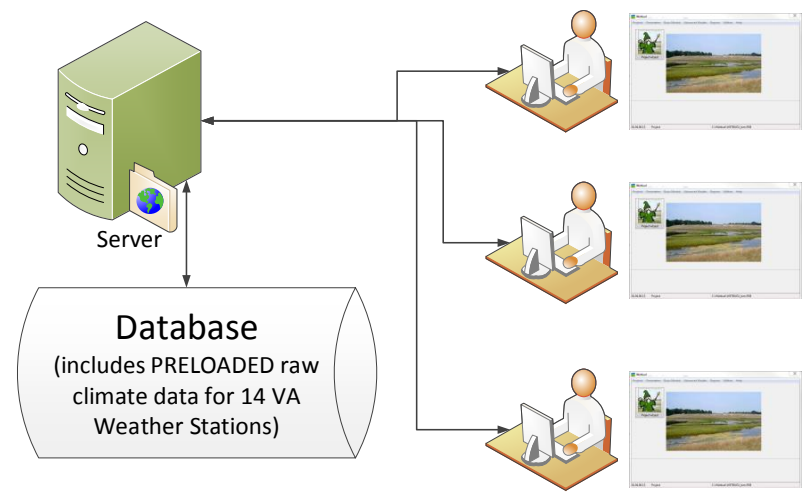

Figure 3. Network Installation.

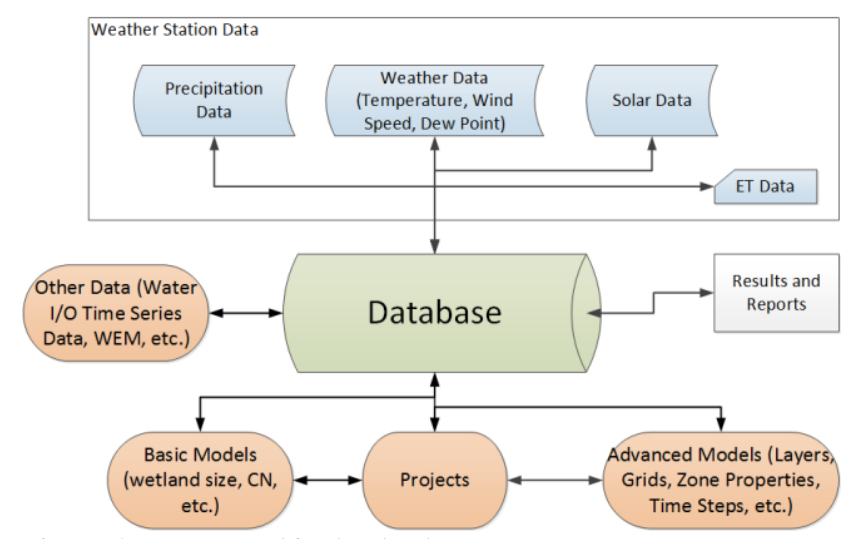

Figure 4. Data stored in the database.

100 distinct modules for data input, configuration, management and report generation (Figure 4).

\section{Design Considerations}

A number of factors were considered when designing the Wetbud software package. Some of these factors are listed below, grouped by category.

\subsection{Projects and scenarios}

Wetbud needs to access and process a large amount of data in order to calculate the water budget for a wetland area. Results need to be easily accessible for charting and/or exporting to Excel files. As Wetbud is a design tool, multiple runs may be needed before the optimum design is reached and the setup and results for these alternate runs may need to be kept as well.

The overarching structure that corresponds to a specific design location is termed a "project." Parametric variations of input parameters can be managed through "scenarios". A project may include an unlimited number of basic and/or advanced scenarios. Site-specific data, such as well information, ground water information, etc., is stored at project level, so that all Project Scenarios can access it.

Basic scenarios can be simplistic or sophisticated depending on the level of analysis. Scenarios allow multiple different runs under a project where the user can modify model parameters (e.g., physical parameters, potential evapotranspiration method, input and outputs, wetland size, weir settings, reference weather station, etc.) without having to duplicate site information under a new Project. Scenarios within a Project can also be copied for user convenience.

Data used in Basic scenarios may be constants or time series (precipitation, ET, groundwater I/O, weir elevations, etc.). In addition, groundwater time series may be generated via a built-in WEM algorithm (Dobbs 2013, Whittecar et al 2017). Also, stream overbank time series may be generated via a built-in algorithm. All Basic scenario data results are automatically stored in the Wetbud Database.

Advanced scenarios are solved using MODFLOW (MODFLOW 2005 or MODFLOW-NWT). Advanced modelling is more complicated since data need to be "translated" in order to be MODFLOW-compatible. Tools have been developed that allow an easy transition from typical weather data time series to input data compatible with MODFLOW.

Calculations for Basic scenarios are performed on a monthly basis; calculations for Advanced scenarios are typically performed on a daily basis.

\subsection{Climate data}

Wetbud can easily manage a large volume of climate data. Some of its features include:

- It can automatically import climate data (precipitation, weather, solar) directly from the US National Oceanic and Atmospheric Administration (NOAA) website, the Natural Resources Conservation Service (NRCS) site, and other sites.

- Climate data can also be imported manually for private weather stations.

- Evapotranspiration (ET) data can be calculated based on different methods such as Penman-Monteith (Jensen et al 1990), Thornthwaite (1948), or imported manually.

- Once climate data are imported and checked, they are available to use in different projects.

- Generated climate based data, such as ET, are also available to use as input to different projects.

- Climate data are tied to weather stations; a weather station can be a public or a private station.

- Importing and exporting of climate data is fully supported.

Note that the most time-consuming part of setting up a project and scenario is establishing a good set of weather data, i.e. precipitation data, regional temperature and wind data, and solar data. Once a good data set is established, the user can proceed to setup a project and basic or advanced scenarios. It is recommended that a basic scenario is run first even if, ultimately, an advanced scenario will be used for the design.

Wetbud currently features preloaded weather and climate data for 14 Stations in the state of Virginia, USA.

\subsection{The dry, normal and wet years}

Permit applications to allow for wetland disturbance or approval of new wetland construction often require water budget analyses of a typical dry, normal, and wet year.

Wetbud selects these years from the thirty-year record used for WETS table statistical analyses (USDA, NRCS) 
which, in part, sort years in that period based on total annual precipitation.

Using a procedure described in McLeod (2013), Wetbud determines if years classified as wet, normal, or dry (WND) based on total annual precipitation also have a wet, normal, or dry spring, respectively ("spring" = March-June). For example, a year that is classified as wet based on total annual precipitation that does not meet the wet spring criteria is rejected as a 'wet' year and another year must be selected as 'wet'. Figure 5 presents a typical log for such a calculation.

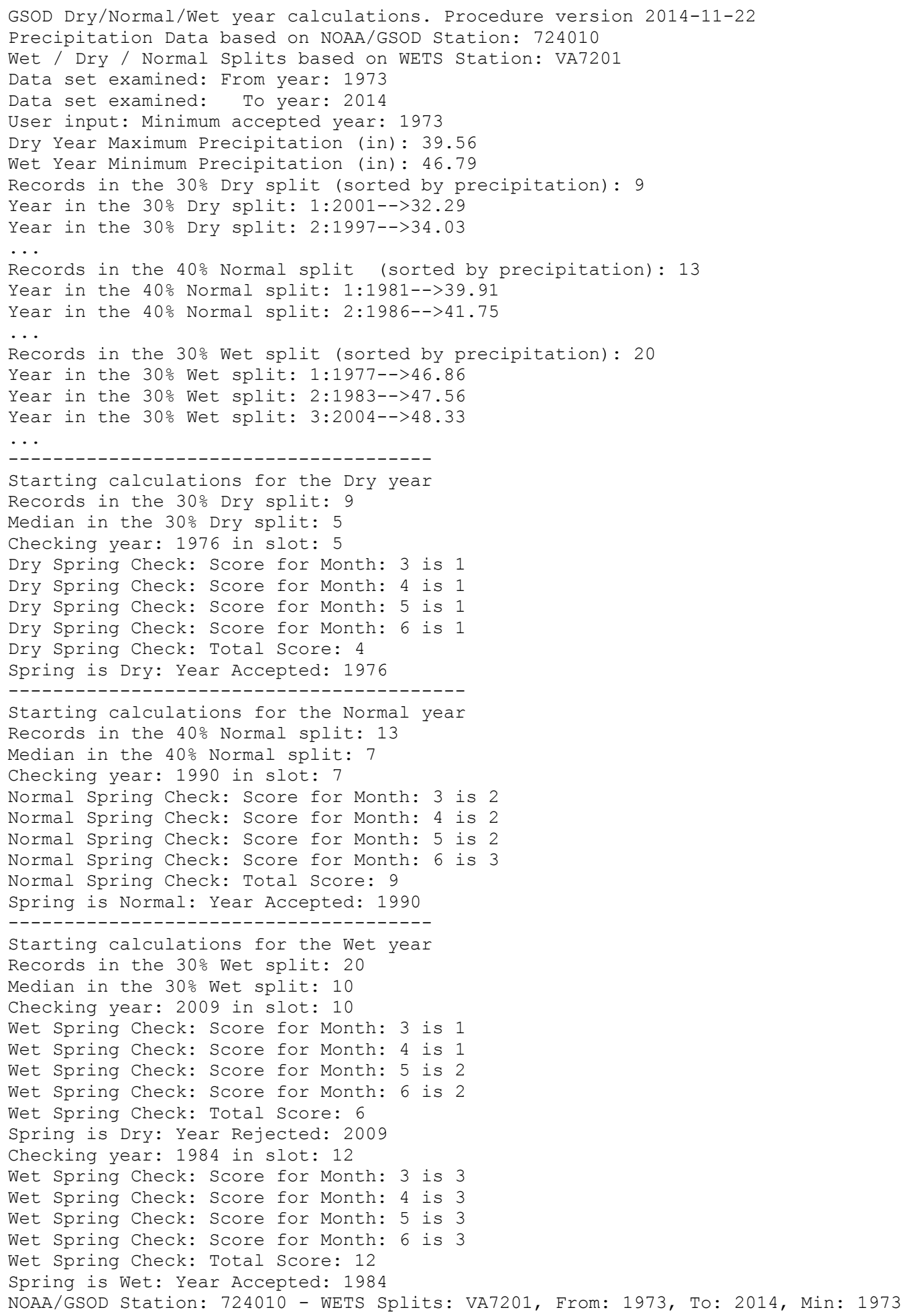

Figure 5: Sample Wet-Dry-Normal year calculation for NOAA station 724010. 


\section{Example Case Study}

Wetbud has been tested at several sites within the Piedmont and Coastal Plain Physiographic Provinces of Virginia (Neuhaus 2013, Dobbs 2013, Hiza 2017, Stone 2017). One such case study was performed at a natural wetland located within Pocahontas State Park (PSP) in Chesterfield, Virginia, USA. Much of the data presented here comes from work done for a master's thesis by K. Dobbs (2013).

\subsection{Study site}

The study area is a 0.45 -ha freshwater, forested wetland located on the floodplain of a small, unnamed perennial stream (lat: 37.34882, lon: -77.58345). The floodplain is approximately $35 \mathrm{~m}$ wide at the study area. The adjacent stream channel is approximately $1.5 \mathrm{~m}$ wide from bank to bank and approximately $1.0 \mathrm{~m}$ deep. There is little physical evidence of overbank flow, suggesting the stream contributes water to the wetland only during extreme rainfall events across the local watershed (less than $2.5 \mathrm{~km}^{2}$ ). Local topography consists of gentle to moderately sloping hills underlain by the Petersburg Granite with local relief being less than $30 \mathrm{~m}$. This combination of gentle topography consisting of sandy soils over weathering granite, and a mean annual precipitation of $113 \mathrm{~cm}$, results in a significant groundwater contribution via toe-slope seepage into the wetland (Dobbs 2013).

\subsection{Basic scenario}

The Basic Scenario was developed to include inputs from precipitation, direct runoff, stream overbank flow, and groundwater. Water left the model area via evapotranspiration, groundwater seepage, and cresting the stream levee and entering the adjacent stream. The magnitude of the weather-related inputs and outputs were determined by referencing weather data from Wetbud's preloaded dataset for the Richmond International Airport NOAA weather station.

The model area, referred to in Wetbud as the 'Constructed Wetland Area,' was 0.45 ha. The total area of the watershed for direct surface runoff was 3.04 ha, with a NRCS curve number of 66 . Groundwater-in was calculated by Wetbud for typical WND years using the Effective Monthly Recharge Model (WEM) routine within Wetbud (Whittecar et al 2017). The WEM routine was calibrated using head data, from locations in the uphill area adjacent to the wetland as well as the toeslope within the wetland (7.62 m apart), collected from May of 2011 to August of 2012. WEM routine calibration resulted in predictions of head elevations with a RMSE of $15.6 \mathrm{~cm}$ relative to the observed head elevations at the uphill well and a RMSE of $14.3 \mathrm{~cm}$ at the toeslope well. The WEM algorithm then applied head predications for the hillslope and toeslope wells for typical WND years via Darcy's Law to estimate the groundwater flux into the site through the 1-m deep sediments along the 56.4-m toeslope boundary of the wetland. The hydraulic conductivity used to represent the sediments at the toeslope was set to $8.6 \times 10^{-6} \mathrm{~m} / \mathrm{s}$. Additionally, stream overbank contributions were estimated using Wetbud's integrated version of the NRCS Dimensionless Unit Hydrograph routine.

Using the conditions described above for a custom time period, during which observed head elevation data were recorded, the Basic Scenario resulted in head predictions with a RMSE of $18.1 \mathrm{~cm}$ and Nash-Sutcliffe model efficiency coefficient of 0.45 . Nash-Sutcliffe values range from $-\infty$ to 1.0 , with 0 indicating a model that is as efficient as using the mean of the observed data and 1.0 being a perfect match to the observed values (Nash and Sutcliffe 1970). Users may employ the 'Calculated vs. Observed Levels' tab (as seen in Figure 6) to validate their models prior to using them to predict water levels for typical WND years. The output from this model indicates Wetbud is capable of reliably predicting head elevations and that adjustments to the parameters in the model, that are meant to represent changes in the design conditions of the wetland, will be accurately reflected as changes in predicted head elevations for typical WND years. While the output from this model is acceptable, the predicted head value for the first month in the time series is significantly higher than the observed head value $(62.48 \mathrm{~m}$ vs. $61.94 \mathrm{~m}$, respectively). As stated earlier, this model references one of the preloaded regional weather stations packaged with Wetbud. While it is convenient to use these preloaded stations, and they are capable of accurately predicting head elevations, there will be times when the weather data that was recorded at the regional station will be different from the weather data, or patterns, from the closest possible station to the site. For this water budget, the Richmond International Airport (approx. $30 \mathrm{~km}$ from site) reported a total of $18.1 \mathrm{~cm}$ of precipitation during August of 2011, with $13.1 \mathrm{~cm}$ occurring on August $28^{\text {th }}$. Conversely, the Winterpock station (GHCN:USC00449213, approx. $6.5 \mathrm{~km}$ from site) reported a total of $13.3 \mathrm{~cm}$ of precipitation during August of 2011, with $8.6 \mathrm{~cm}$ occurring August $28^{\text {th }}$. While both stations reported intense precipitation on August $28^{\text {th }}$, the difference in the reported precipitation was significant enough to cause the model to predict overbank flow during August of 2011 which flooded the model wetland. Users referencing preloaded stations should be aware of the possibility for large isolated storms to affect predicted or observed head values within their models or wetland sites.

\subsection{Advanced scenario}

The Advanced Scenario was constructed using a model grid consisting of 50 rows and 41 columns, each $1 \mathrm{~m}$ by $1 \mathrm{~m}$, and 5 layers with varying hydraulic conductivity and storage values representative of the vegetation and underlying sediments. Elevations for each cell were approximated from topographic maps and field observations.

Precipitation and evapotranspiration were applied uniformly to the top layer of the model. WEM was not used to estimate groundwater inputs into the Advanced Scenario. Potential evapotranspiration was estimated via the PenmanMonteith method and calculated by Wetbud. Wetbud applied changes to the model on a daily basis in units of meters per second.

Figure 7 shows daily head predictions for 1990 (normal 


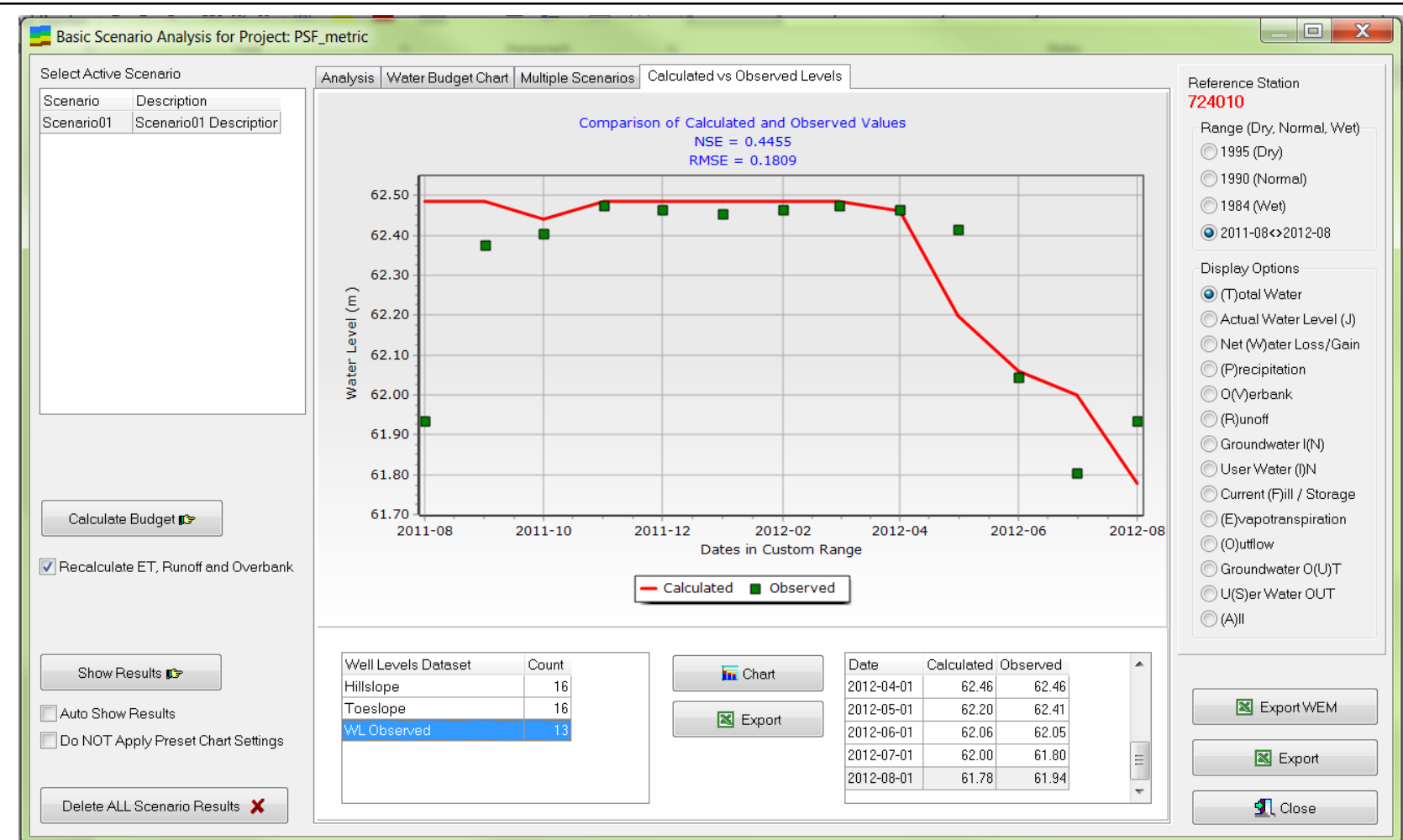

Figure 6. Basic Model observed and predicted head elevations for custom time period. Red line represents predicted head levels. Green squares represent observations of water levels recorded at the site being modeled. NSE $=$ Nash-Sutcliffe, RMSE $=$ root mean square error.

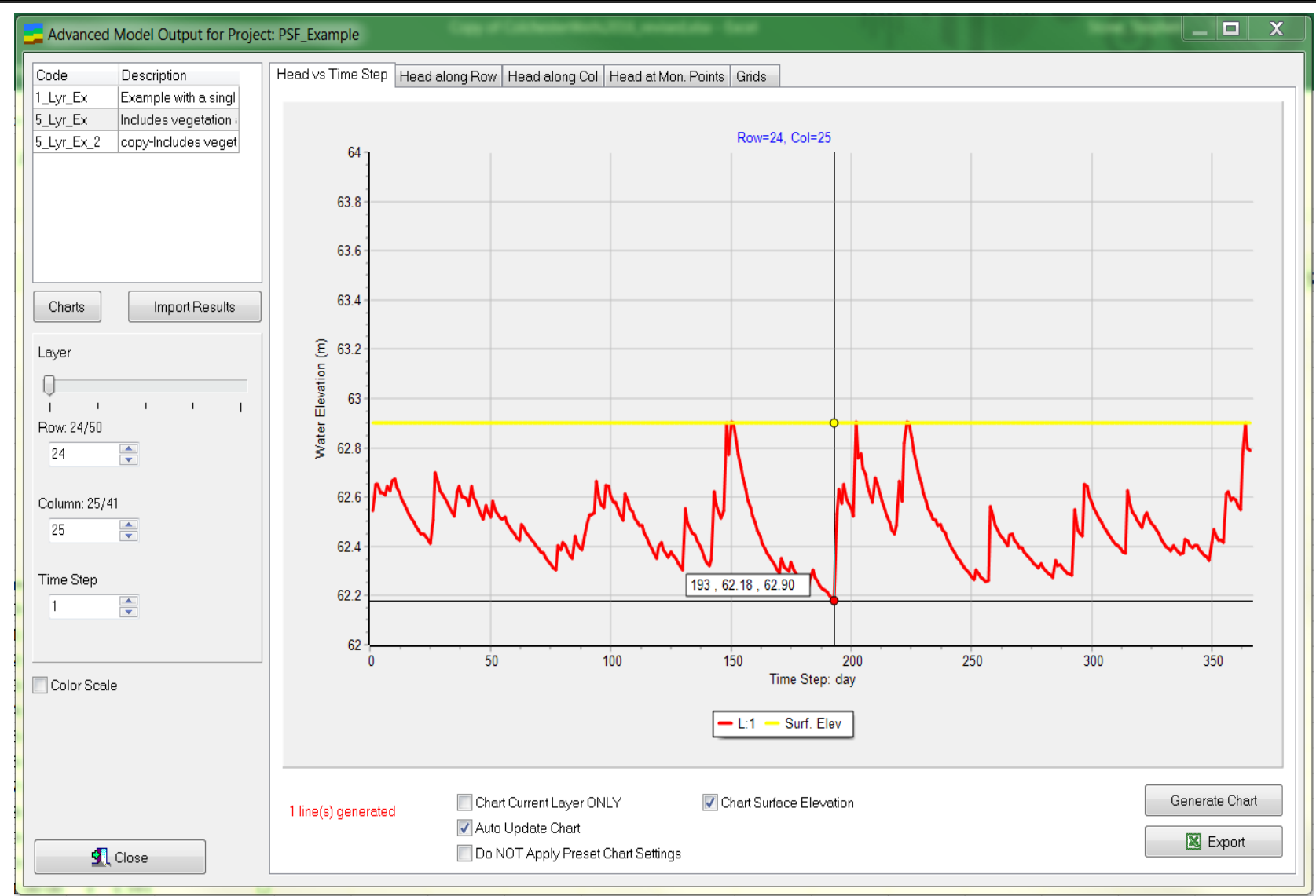

Figure 7. Advanced Scenario daily hydrograph for typical normal year, 1990. Red line represents daily predicted head values. Yellow line represents the ground surface elevation at the cell for which head predictions were made. 
year) for the site. Head predictions shown in Figure 7 are from a cell representative of a location within the area that should be a wetland. During the growing season of the modeled period, the water levels occurred close enough to the surface for the site to be considered a jurisdictional wetland.

\section{Conclusions}

$\mathrm{Be}$ it for land reclamation projects associated with mining activities or mitigation for other land development projects having environmental impacts, developers should consider using Wetbud to design successful mitigation wetlands.

Wetbud's abilities to (a) retrieve and store NOAA weather station data, (b) to estimate PET via multiple methods from NOAA datasets or observations made at the proposed wetland site, (c) to include user-generated estimates of inputs and outputs for their sites to represent known fluxes, (d) to incorporate overbank flow from adjacent streams and account for multiple inlet structures, and (e) to use WEM to estimate groundwater fluxes for typical WND years that lack observed head elevation data result in a software package that streamlines the production of reliable water budgets for a wide variety of mitigation wetland settings. For more complicated settings, or for research purposes, users may employ the Advanced Scenario tools and create water budgets for sloping wetlands, or wetlands with variable topography, and dynamic sources and losses of water that can vary spatially and through time.

The case studies that have been performed in conjunction with the development of Wetbud have influenced the routines and user-interface within Wetbud. Additionally, these case studies have validated the model's ability to accurately predict head elevations.

Wetbud is now available for public use as freeware from www.landrehab.org/WETBUD and runs in Windows environments.

\section{Acknowledgements}

This research project is made possible through the financial support from Wetland Studies and Solutions, Inc.'s Wetland Research Initiative and the Peterson Family Foundation. In particular, we want to thank Mike Rolband and Jennifer Van Houten of WSSI for their continued support of this work. We also appreciate the hard work of the many graduate students who have helped to test Wetbud during its development.

\section{References}

Dobbs, K.M., 2013. Evaluating the contribution of groundwater to wetland water budgets, Central Piedmont, Virginia. M.S. Thesis, Department of Ocean, Earth, and Atmospheric Sciences, Old Dominion University, Norfolk.

Harbaugh, A.W., E.R. Banta, M.C. Hill and M.G. McDonald, 2000. MODFLOW-2000, the U.S. Geological Survey modular ground-water model - User guide to modularization concepts and the ground-water flow process. USGS Open-File Report 00-92, U.S. Geological Survey, Reston.
Harbaugh, A.W. 2005. MODFLOW-2005, the U.S. Geological Survey modular ground-water model-the ground water flow process. USGS Techniques and Methods 6-A16. U.S. Geological Survey, Reston.

Hiza, B.S., 2017, Groundwater and tidal controls on wetland hydrology, Julie J. Metz wetland mitigation bank, Woodbridge, Virginia. M.S. Thesis. Department of Ocean, Earth, and Atmospheric Sciences, Old Dominion University, Norfolk. (in press)

Jensen, M.E., R.D. Burman, and R.G. Allen, 1990. Evapotranspiration and irrigation water requirements (ASCE Manuals and Reports on Engineering Practice No. 70). American Society of Civil Engineers.

McLeod, J.M., 2013, Hydrogeologic analysis of factors that influence pitcher plant bog viability at the Joseph Pines Preserve, Sussex. Virginia. M.S. Thesis, Department of Ocean, Earth, and Atmospheric Sciences, Old Dominion University, Norfolk.

Nash, J.E. and J.V. Sutcliffe, 1970, River flow forecasting through conceptual models part I - A discussion of principles. Journal of Hydrology, 10: 282 - 290.

Neuhaus, E., 2013, Evaluation of a water budget model for use in wetland design. Virginia Polytechnic Institute and State University, Blacksburg.

Niswonger, R.G., S. Panday and M. Ibaraki. 2011. MODFLOW-NWT, A Newton formulation for MODFLOW-2005. U.S. Geological Survey Techniques and Methods 6-A37. U.S. Geological Survey, Reston.

Stone, S.F., 2017, Hydrologic response caused by Wetland Expansion at Huntley Meadows Park in Hybla Valley. Virginia, Department of Ocean, Earth, and Atmospheric Sciences, Old Dominion University, Norfolk. (in press)

Thornthwaite, C.W., 1948. An approach towards a rational classification of climate. Geographical Review, 38: 55 94.

USDA (U.S. Department of Agriculture), 2017. Natural Resources Conservation Services (NRCS). https://www.wcc.nrcs.usda.gov/normals/30year_normal s_data.htm (accessed 28.04.17).

Whittecar, G.R., K.M. Dobbs, S.F. Stone, J.M. McLeod, T.L. Thornton and J.C. Smith, 2017. Use of the effective monthly recharge model to assess long-term water-level fluctuations in and around groundwater-dominated wetlands. Ecological Engineering, 99: 462 - 472. 